\title{
Széll Tamás
}

\author{
Sohár Pál, ELTE TTK Kémiai Intézet*
}

A határainkon is túlterjeszkedő magyar vegyésztársadalmat ismét fájdalmas veszteség érte: elhunyt Széll Tamás professzor a Kémiai Tudományok Doktora, a Szegedi Tudományegyetem (akkori nevén József Attila Tudományegyetem) Alkalmazott Kémiai Tanszékének egyik megalapítója és egykori vezetője, az egyetem habilitált címzetes egyetemi tanára, az UN New York City-i International School Science Department volt igazgatója, a New York Academies of Sciences, az American Chemical Society és a Royal Institute of Chemistry tagja.

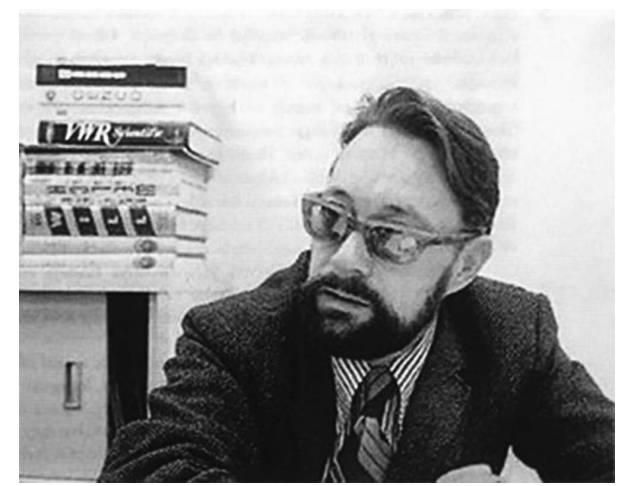

1. ábra. Széll Tamás professzor (1926-2020)

Széll Tamás 1926-ban Herény községben (ma Szombathely városrésze) született. Középiskolai tanulmányait a szombathelyi Premontrei, majd a pécsi Pius jezsuita gimnáziumban végezte. Kitűnő érettségije után a kötelező katonai szolgálatra önkéntesnek jelentkezett, mégpedig nagyapja és édesapja nyomdokaiba lépve huszárnak - az úgynevezett gyorsan-mozgó fegyvernemet választva. Németországi frontszolgálat után előbb amerikai, majd belga hadifogságba esett. Sikerült 1944-ben hazaszöknie. A Budapesti Müszaki Egyetemen szerzett kitüntetéses vegyészmérnöki (1950), majd „summa cum laude” minősítéssel műszaki doktori (1961) diplomát. Egyetemi tanulmányait igen nehéz anyagi helyzetben, nyomorúságos körülmények között végezte. Az akkori nagy ínség idején a cisztercita szerzetesek szegény diákok megsegítésére ebédeltetési akciót szerveztek: a diákok minden nap más-más családnál ebédeltek. Tamás professzora és „földije” Náray-Szabó István akadémikus, a hazai krisztallográfia megteremtője családjában is volt néhányszor „kosztos diák”. 1950-ben a József Attila Tudományegyetemen kezdte meg szakmai pályafutását. Gerecs Árpád professzor meghívására, vele közösen alapították meg az Alkalmazott Kémiai Tanszéket, amelynek Gerecs professzor Budapestre távozása után, vezetője lett. Szegeden 1958-ban kémia szakos középiskolai tanári és egyetemi doktori diplomát szerzett. Megszerezte előbb (1960) a Magyar Tudományos Akadémia kandidátusi, majd már az Egyesült Államokból külön e célból hazatérve, 1974-ben a Kémiai Tudományok Doktora fokozatot.

Széll Tamás 1950-től, adminisztratíve negyedszázadon át, 1975-ig, ténylegesen Amerikába távozásáig, 1970-ig volt a JATE Alkalmazott Kémiai Tanszékének oktatója, 1955 és 1958 között vezetője. [1] A megalapításakor Gerecs professzorral és egy technikussal alkották a háromszemélyes Alkalmazott Kémiai tanszéket. A kémiai technológia tárgy előadása és a hozzá kapcsolódó gyakorlat vezetése mellett Széll professzor géprajzot is oktatott. Egy halálos kimenetelü laboratóriumi baleset hatására, az ő javaslatára indult meg komolyabb tárgyként a munkavédelem oktatása a JATE-n. Társszerzőkkel összeállítottak egy „Munkavédelmi útmutató”-t, amely aztán követendő mintául szolgált a többi hazai egyetem számára. Ö volt a szakszervezet „munkavédelmi felügyelő”-je. Ez jelentette „társadalmi munkáját”, ami akkoriban minden előléptetés, fizetésemelés, kitüntetés, stb. elöfeltétele volt és legtöbbször valamilyen „,pártmunkát” (párttagságot, agitációs feladatok végzését, ideológiai szemináriumokon részvételt, előadástartást, pártrendezvények szervezését, stb.) takart. Így sikerült mentesülnie az elveivel összeegyeztethetetlen, de akkor kikerülhetetlen kötelezettség teljesítése alól.

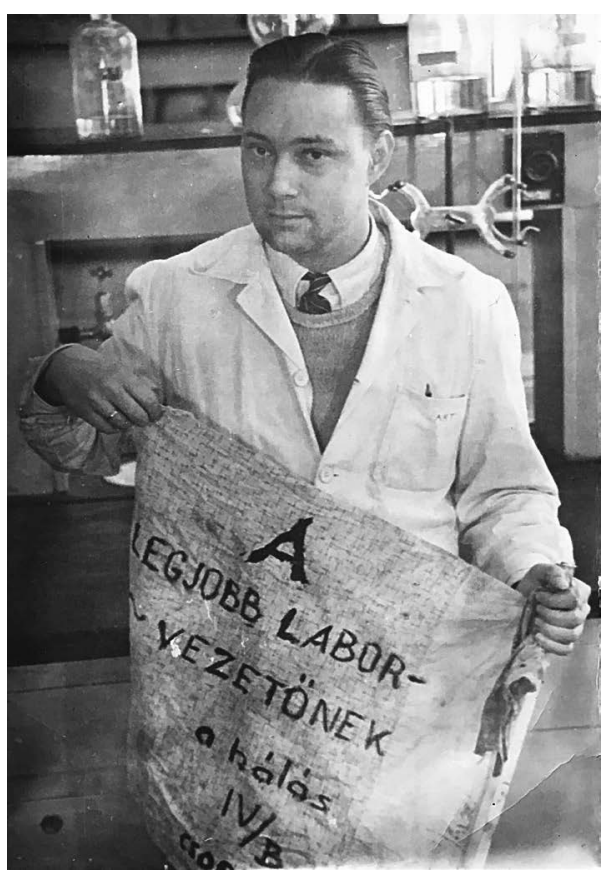

2. ábra. Széll Tamás a laboratóriumban, kezében a hallgatóitól kapott elismerő feliratú „,plakáttal” 
Széll Tamás 1952-ben megnősült. Feleségét, Molnár Klárát hallgatóként ismerte meg, aki Szegeden szerzett vegyész diplomát. Két leányuk, négy unokájuk és két dédunokájuk van.

Timea, az idősebbik leány a Columbia egyetem Barnard Kollegiumában Senior Lecturer, programvezető. Főként a középkor irodalmával foglalkozik. A fiatalabb leány, Ágnes Hibbs, sikeres, közkedvelt fogorvos a vermonti Burlingtonban.

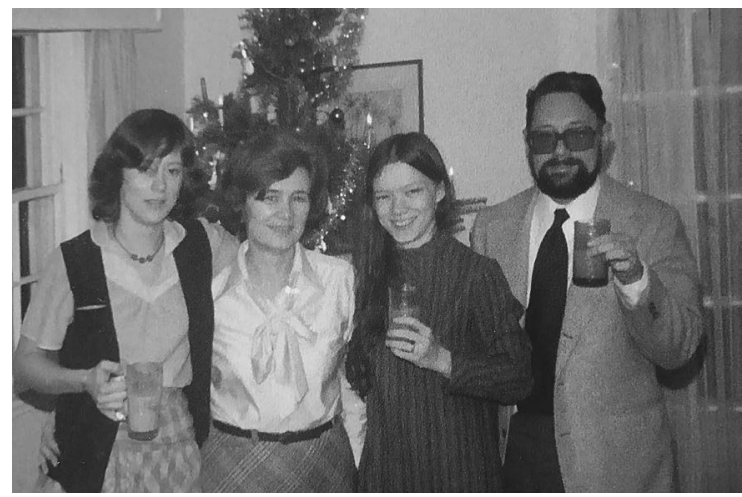

3. ábra. A Széll-házaspár két leányukkal 1979 karácsonyán

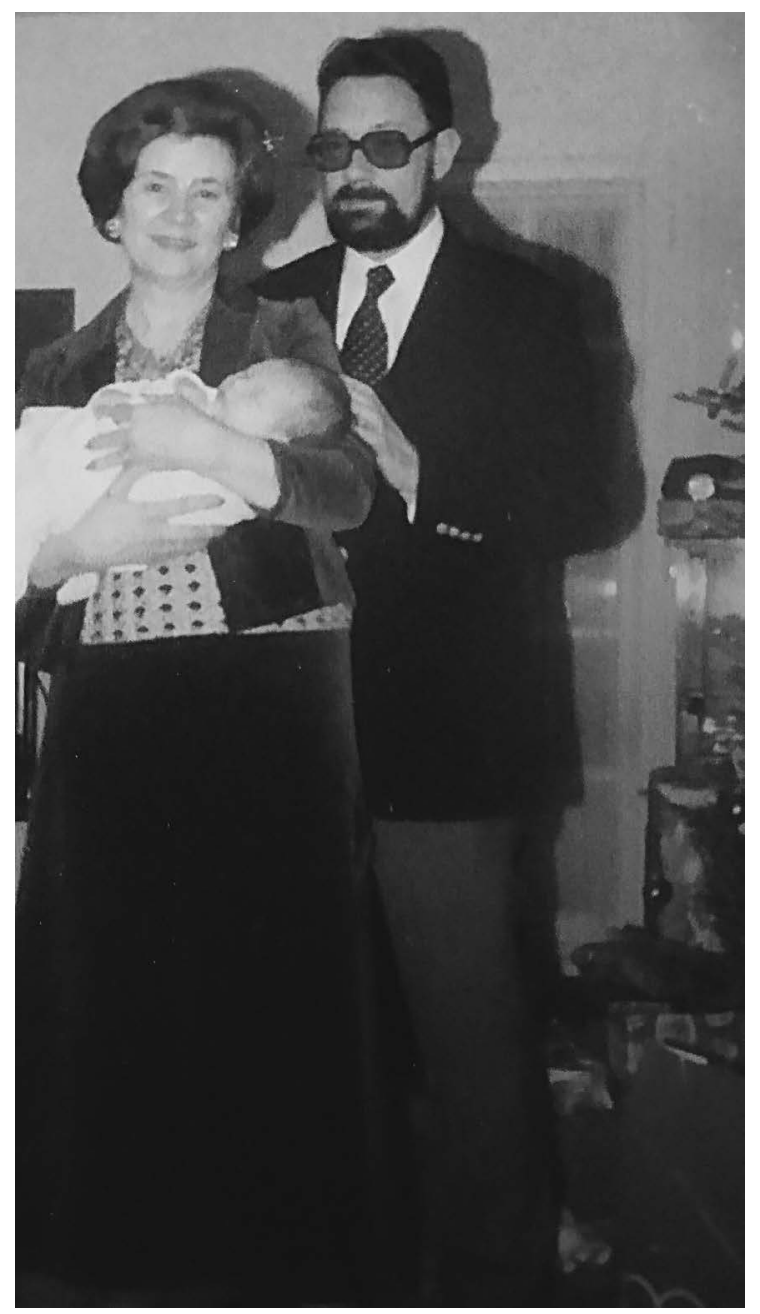

4. ábra. A boldog nagyszülök unokájukkal 1982-ben
Az UN New Yorki Nemzetközi Iskolája versenypályázatán 1970-ben kezdődő ötéves ösztöndíjat nyert, ahol aztán oktatóként müködött, s ahonnan a természettudományi részleg vezetöjeként 1989-ben vonult nyugdíjba. Közben 1974 és 1982 között az UNIS Dreyfus Kutatóprogram igazgatójaként is müködött. Az UN ösztöndíjat felsőfokú angol nyelvvizsgájának köszönhette (ez akkoriban még ritkaság volt). Nyelvtudását egyéves kanadai (Ottawa, 1963/65) és negyedéves indiai (Calcutta, Ahmedabad, Jaipur, Madras, 1967) tanulmányútjai során tökéletesítette. Ösztöndíjas éveit családjával együtt töltötte az Egyesült Államokban. Mire eltelt az öt év, egyik lánya férjhez ment egy amerikaihoz és az Iskola is marasztalta. Ezért hosszabbítást kért, amit azonban nem kapott meg. Hosszas vívódás után végül úgy döntött, hogy engedély nélkül kinn marad, azaz akkori felfogás szerint disszidál. Súlyos elhatározás volt, mert így hosszú évekre lehetetlenné vált hazatérése. Távollétében két év börtönre ítélték és csak évek múltán, u. n. konzuli útlevéllel térhetett haza rövid látogatásokra. Döntésének fö oka volt, hogy felesége nem volt hajlandó visszatérni, $\mathrm{s}$ ott hagyni leányait, $\mathrm{s}$ leendő unokáit. Az is a maradásra késztette, hogy itthon közben betöltötték tanszékvezetői pozícióját, sőt egyetemi státuszát is megszüntették. Az állásvesztés mellett a származása és nézetei miatti korábbi méltánytalanságok, mellőzések folytatódásával is számolnia kellett. De hazájának elhagyása súlyos lelki krízist okozott. Egész életében honvágy és büntudat gyötörte. E sorok írójának nem győzte megköszönni az akkor tőle kapott ,felmentő” sorokat: „A szabad költözködés jogát Dózsa György már több százada kivívta!"

Tamás később elmesélte, hogy visszarepült New Yorkból Bécsbe és a magyar határ közeléből napokon át telefonon próbálta rábeszélni feleségét a hazatérésre, aki azonban hajthatatlan maradt. „Egy drága autóra való pénzt telefonálgattam el akkor" - mesélte. Magyarságára büszke volt, s haláláig hủ maradt hozzá. Hazaszeretete, ragaszkodása a Szülöföldhöz, minden tettében, írásában és szavaiban számtalanszor megnyilvánult. Magyarságát híven megőrizte, magyar állampolgárságát megtartotta, $\mathrm{s}$ ennek mintegy megerősítéséül ragaszkodott, hogy tartalékos főhadnagykénti nyilvántartása fennmaradjon és, hogy vitézzé avassák, feljogosítva őt ezzel a nagybátyjától megörökölt cím viselésére. Hasonlóképpen ragaszkodott szűkebb szülőföldjéhez, Szombathelyhez, a vasi, örségi tájhoz. A Vasi szemlében rendszeresen jeletek meg írásai, tájleírások, megemlékezések, méltatások helybéli személyiségekről, családtörténeti, tájnyelvi érdekességekröl szóló értekezések.

Amint ez lehetővé vált, szinte minden évben hazautazott (félszáznál is többször repülte át az Óceánt, hogy hazatérhessen), feleségével, vagy egyedül, sőt unokáit is hazahozta, hogy megismerjék öseik földjét. Tanfolyamokat, előadásokat tartott, ismételten érettségi elnöki feladatot vállalt, hazarepült megvédeni akadémiai doktori értekezését, a szegedi egyetemen habilitált, végig látogatta rokonait, barátait és a temetőket, ahol családtagjai, rokonai nyugszanak. Ikertestvérével való meghitt kapcsolatát a földrészeket 
elválasztó tenger és a több ezer kilométeres távolság sem tudta fellazítani. Levelezésük köteteket tesz ki - közel ezer levélváltásuk őrzi szoros kapcsolatuk folytonosságát.

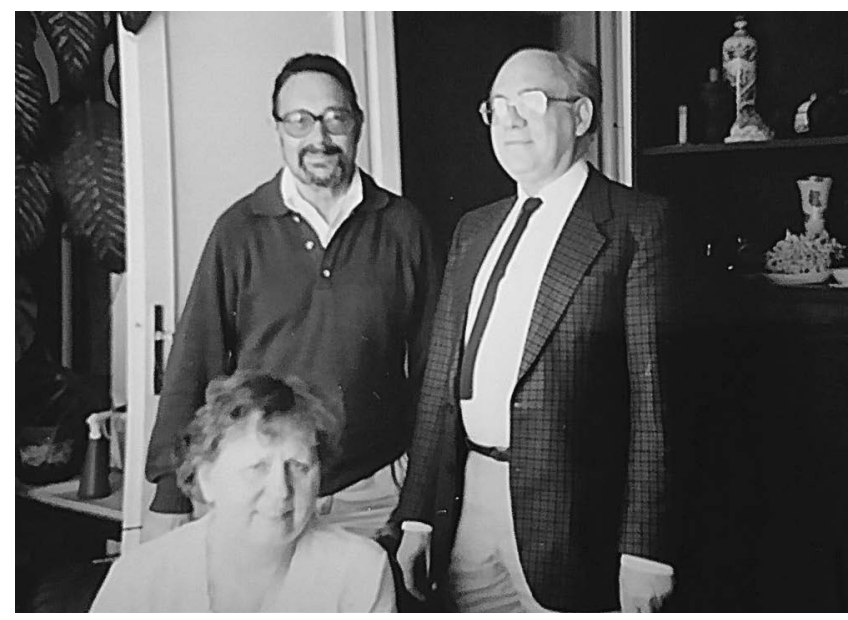

5. ábra. Széll Tamás a szerzővel és feleségével egyik látogatása alkamával otthonukban

Apropó, ikertestvére! Széll Kálmán a szombathelyi Markusovszky kórház előbb sebész, majd aneszteziológus főorvosa, a magyar aneszteziológia és intenziv terápia egyik hazai uttöröje, a város díszpolgára, a KDNP megyei elnöke és polgármester-jelöltje, s kitünő visszaemlékezés-kötetek szerzője. Róla mesélte Tamás az alábbi kedves kis történetet: Diákkorában bliccelt a villamoson, s az ellenőr elcsípte. Hogy hívnak kisfiam - kérdezte az ellenőr. Széll Kálmánnak - jött a válasz. Igen! - Én meg Vörösmarty Mihály vagyok - mondta az ellenőr - egy pofon kíséretében. Sajtelme sem lehetett az ellenőrnek, hogy felmenői révén Széll Tamást nemcsak a Magyar Királyság 12., a „törvény, jog és igazság” miniszterelnökéhez, de a nagy költőhöz, sőt Arany Jánoshoz is rokoni szálak füzik. (A Széll-család történetében más történelmi név, mégpedig a Deák Ferencé is előfordul, aki közeli jó barátja volt a miniszterelnöknek.) Tamás erröl szinte sohasem beszélt, vagy írt. Nem tartotta fontosnak. Úgy vélte, mindenkit csupán csak saját tettei, jelleme minősítenek, érdemeit magának kell megszereznie.

Széll Tamás barátságos, vidámtermészetű, szeretetreméltó ember volt. Kitűnő oktatóként tanítványai rajongtak érte, kollégái is kivétel nélkül szerették, $\mathrm{s}$ igen sok barátja volt. Szerette az állatokat, föként a kutyákat és lovakat. New Yorkban, sokemeletes házban laktak. Egy napokig tartó áramszünet idején, amikor a toronyházakban lakók tucatjával szabadultak meg háziállataiktól, hogy mentesüljek a kutyasétáltatással járó emeletmászástól, Tamás minden nap, alkalmanként többször is, sok emeletet mászva, zokszó nélkül vitte kutyáját a szabadba.

Széll professzor szakmai tevékenysége az oktatásra koncentrálódott, de kiváló kutató is volt. Kutatási területe a szerves szintetikus kémia, ezen belül a KostaneckiRobinson-féle [2] és az aldol kondenzáció, [3] s így a kalkonok [4-17], flavonok [18] és kromonok szintézise [19-22], az $\mathrm{AlCl}_{3}$-katalizált folyamatok: a Fries-átrendeződés [23-26] és a Friel-Crafts-reakció [27, 28] volt. Egy új kromon-szintézis is füződik nevéhez. A flavanoidok kutatásában fontos szerepet játszó Kostanecki-Robinson reakció mechanizmusának vizsgálata során felismert egy u.n „,szomszédcsoport-részvétel"-lel lejátszódó folyamatot. [2]

Tudományos publikációinak jegyzékét - ha egyáltalán létezik - sajnos nem sikerült megtalálni, csupán egyik tanítványának (Prof. emer. Zarándi Márta) az MTMT-ben meglévő közös közleményeik [2-4] és a Szegedi Egyetemi Almanachban [1] felsorolt főbb müveinek részben hiányos adatai szerepelnek a csatolt referencia-listán, továbbá két közös dolgozatunk [6, 19], amelyek a fent említett kutatásokhoz kapcsolódnak. Ezeken kívül még sikerült megtalálni néhány további Széll-közleményt az interneten, de a lista korántsem teljes. Az 1960-as években kezdődő kutatási együttmüködésünk épp akkoriban „fordult termőre” (értek meg közös munkáink a publikálásra), amikor Tamás az USA-ba költözött. Több közlésre elökészített közös munkánk első fogalmazványa végleg az asztalfiókban rekedt. Új „hazájában” az egzisztenciateremtés, a rábízott új intézet müködésének megszervezése, irányítása, az oktatási anyag összeállítása és az adminisztratív feladatok, mindenekelőtt pedig az oktatás hosszú időre a kutatómunka felfüggesztésére kényszerítették. Sok év (majd két évtized) multán tán nosztalgiából - előbányászott iratai közül egy még itthon-létekor félbemaradt közös munkát, és ebből - a készülő kézirat az óceánon át többszöri utat megtéve - egy alaposan megkésett közlemény [7] született.

Széll Tamás pedagógusi elkötelezettségét bizonyítja, hogy oktatással kapcsolatos módszertani írásainak [pl. 29, 30] és legsikeresebb tanítványainak jegyzéke viszont több változatban is fennmaradt. A Kémia Tanitása címü lapban 1963 és 2001 között tíz, a Felsőoktatási Szemlében az 1960-as években tucatnyi írása jelent meg, de pedagógia tárgyú cikket publikált a Magyar Kémikusok Lapjában is. [31]

Tanítványai között voltak többek között Bartók Mihály, Beck Mihály, Márta Ferenc, Solymosi Frigyes és Tüdős Ferenc akadémikus, Bajusz Sándor, Furka Árpád, Schneider Gyula, Vincze Irén és Zaránd Márta hazai, valamint J. M. Mayer (Seattle), J. Schimel (Denver) és E. Mario (Cyprus) külföldi professzorok.

Széll professzor munkásságát számos kitüntetéssel ismerték el. Bár magyarországi tevékenysége idején, a kommunista diktatúra éveiben „osztályidegenként” nem tartozott a rendszer kegyeltjei közé és mivel többszöri felszólítás ellenére sem volt hajlandó belépni a Kommunista Pártba folyamatosan zaklatták, sorozatos méltánytalanságok érték, kiemelkedő és sikeres pedagógusi tevékenységét elismerték, s kétszer is megkapta „Az oktatásügy kiváló dolgozója” kitüntetést $(1967,1969)$. Külföldre távozása után is több rangos elismerésben részesítették Birtokosa lett az MCA Catalytic Award (1979), az American Chemical Society Nichols Award (1982) és az ACS Middle Atlantic Regional Award in Chemistry Teaching (1983) kitüntetéseknek. 
Széll Tamás igen nagy műveltségü, széles érdeklődéskörü, sokoldalú, valóságos renaissance alkatú ember volt. Beutazta a fél világot, megfordult öt földrészen, több nyelven beszélt, szerette és ismerte a klasszikus irodalmat és zenét, sokat olvasott és több hangszeren is játszott. A klaszszikus magyar irodalom nagyjainak müveiből szinte hiánytalan, tekintélyes könyvgyüjteménye volt. Szenvedélyes családkutató volt, s nem csak a Széll-család múltja érdekelte. Többek között ezen írás szerzőjének családjáról is talált érdekes dokumentumokat. Gondos levéltári kutatások eredményeként igazolta a felesége rokonságában felbukkanó Gazsó családnév magyar eredetét.

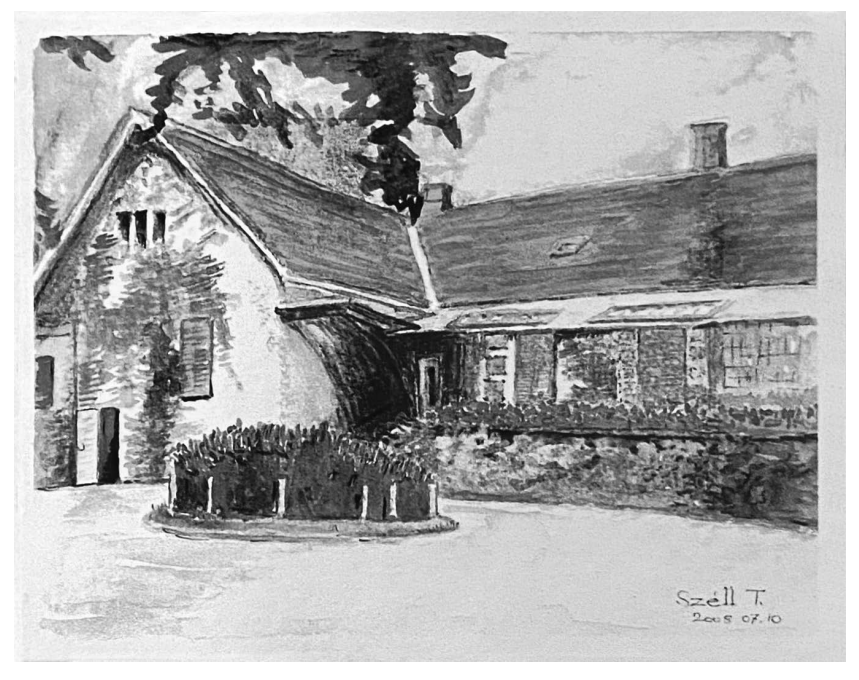

6. ábra. Széll Tamás egy akvarellje

Ügyesen festett, verseket fordított és írt. De kifejtette nézeteit az iszlámról, a környezetvédelem kapcsán pl. az ózonlyukról és a légkör felmelegedéséről, a Föld széndioxid-háztartásáról, a déli harangszó eredetéről. A vasi nyelvjárásról írt tanulmányt, helytörténeti írásai is voltak, s egyebek között megrázó, hiteles leírást publikált hallgató-kori támogatójáról, az igaztalanul meghurcolt nemzetközi tekintélyü tudós Náray-Szabó Istvánról.

Szeretett kirándulni gyalog és kerékpárral, idős korában is rendszeresen sportolt, úszott és kerti munkát végzett. Nyugdíjba vonulását követően Essexben (Vermont) vett házat, hogy Ági leánya és unokái közelében lehessen. Szerette a természetet, a növényeket és állatokat. A szinte érintetlen természeti környezetben zöldséget termesztett, fákat ültetett és élvezettel figyelte, s írta le leveleiben erdei állatok - szarvasok, rókák, farkasok (cowolfok) - „látogatásait”, elnézve az ültetvényeiben okozott károkat is, csupán kedvenc kutyáját, Sámsont féltve a vadak támadásától.

Tamás vallásos, mélyen hívő ember volt. Hitt a túlvilági életben és régóta készült az odaköltözésre. Egyik versében írt erről:

„Csak az lesz boldog, ki ide nézhet, / látja szeretteit, kik még itt élnek... Enélkül ott is magány gyötörne / Örök elválás gyötrelmes lenne."
Végakarata, hogy hamvait hazahozzák szülőhazájába és a herényi temetőben helyezzék végső nyugalomra, s a számára oly kedves vasi táj hantjai örizzék földi maradványait. Immár végét ért félévszázados száműzetése, örökre elmúlt a sok éven át őt szüntelenül kínzó honvágy, begyógyult az egész életén át gyötrő, sajgó seb, amelyet hazája kényszerü elhagyása ütött. Nekünk, családjának, szeretteinek, rokonainak, barátainak, tanítványainak és kémikus pályatársainak megmarad a hazáját odaadóan szerető, magyarságához hüséges honfitársunk, a nagy tudású, sokoldalúan tehetséges és müvelt ember, az elhivatott pedagógus, a kitűnő kémikus, a szeretetre méltó, jó kedélyü, megnyerö, tiszteltet ébresztő személyiség emléke.

\section{Köszönetnyilvánítás}

A megemlékező köszönetet mond mindazoknak, akik segítették, hogy minél teljesebb, hiteles és tárgyilagos lehessen ez az írás, közülük is elsősorban Széll Tamás leányainak, Ágnesnek és Timeának, Kálmán testvérének,továbbá Huszthy Péter professzornak és Schneider Gyula profeszszornak, egykori egyetemi kollégájának.

\section{Közleményjegyzék}

1. Szegedi Egyetemi Almanach 1921-1995. 430 (1996).

2. Széll, T., Eiden, F.: Uber ide Kostanecki - Robinson Reaktion von 2-Hydroxy-formyl acetophenon. Arch. Pharm., 305(2), 81-84 (1972) https://doi.org/10.1002/ardp.19723050202

3. Széll, T., Kovács, K., Zarándi., M., Erdőhelyi, A.: Cyclization of the enol esters of O-acyoxyphenyl alkyl ketones IV.: A kinetic study of the steps of the KostaneckiRobinson reaction. Helvetica Chim. Acta, 52, 2636-2641 (1969) https://doi.org/10.1002/hlca.19690520844

4. Széll, T., Dózsai, L. Zarándi, M ., Menyhárth, K.: Cyclization of the enol esters of O-acyloxyphenyl alkyl ketones-III.: A contribution to the mechanism of the Kostanecki-Robinson acylation 1,2. Tetrahedron, 25, 715-724 (1969) https://doi.org/10.1016/0040-4020(69)85003-9

5. Széll, T., Dudás, Z., Zarándi, M.: New nitrochalcones XII. Acta Univ. Szegediensis, Acta Phys. Chem., 15(3-4), 157-161, (1969) https://doi.org/10.3109/rhe1.1969.15.issue-1-4.24

6. P. Sohár, T. Széll and T. Dudás: New nitrochalcones, XI. Contribution to the sterochemistry of some nitrohydroxychalcones. Acta Chim. Acad. Sci. Hung., 70, 355-368 (1971).

7. T. Széll, M. Sweeney, S. Chadha, P. Sohár: Further thienylchalcones, II. Chem. Ber., 122, 795-796 (1989). https://doi.org/10.1002/cber.19891220428

8. Széll, T., Sohár, I.: New nitrochalcones, IX. Canadian J. Chem., 47, 1254-1258 (1969) https://doi.org/10.1139/v69-207

9. Széll, T., Eastham, A. M., Sipos, Gy.: New nitrochalcones, VII. Canadian J. Chem. 42(11), 2417-2423 (1964). https://doi.org/10.1139/v64-356

10. Széll, T.: Synthesen und Eigenschaften von Nitro-hydroxychalkonen. Chem. Ber., 91(12), 2609-2614 (1958). https://doi.org/10.1002/cber.19580911211 
11. Sipos, Gy., Furka, Á., Széll, T: Kinetische Untersuchung der basenkatalysierten Chalkonbildung Monatsh. Chem., 91. 643-652 (1960) https://doi.org/10.1007/BF00899802

12. Sipos, Gy., Széll, T.: Neue Nitro-Kalkone, VIII. Acta Univ. Szegediensis, Acta Phys. Chem., 11(1-2), 43-46 (1965) http://acta.bibl.u-szeged.hu/id/eprint/23656

13. Széll, T.: Synthese und Eigenschaften von Nitro-hydroxychalkonen, II Chem. Ber., 92(7), 1672-1674 (1959) https://doi.org/10.1002/cber.19590920730

14. Széll, T.: Notiz über die Herstellung einiger ChalkonAnaloga. Synthese und Eigenschaften von Nitro-hydroxychalkonen, III Chem. Ber., 93(8), 1928-1929 (1960) https://doi.org/10.1002/cber.19600930836

15. Széll, T., Brand, A., Ratanathanawongs, S.: Two new thia chalcones. J. Chem. Eng., 26(2), 230 (1981) https://doi.org/10.1021/je00024a043

16. Széll, T. : Unyi, R. É. M.: Condensation of Hydroxynitroacetophenones with Aromatic Aldehydes in the Presence of Hydrogen Chloride J. Org. Chem., 28(4), $1146-1147(1963)$ https://doi.org/10.1021/jo01039a515

17. Széll, T., Sipos, G. Neue Nitro-calkone, V. Liebigs Annalen Chem., 641(1), 113-115 (1961). https://doi.org/10.1002/jlac.19616410112

18. Széll, T., Zarándi, M.: Synthesis of benzylidene-flavanones Canadian J. Chem., 46, 1571-1572 (1968) https://doi.org/10.1139/v68-257

19. Sohár, P., Széll, T., Dudás, T., Sohár, I.: Structure of nuclear C-methylated chromones. Tetrahedron Letters, 1101-1102 (1972).

20. Széll, Gy. Schöbel, L. Baláspiri: Cyclization of enolesters of $o$-acyloxyphenyl alkyl ketones, II : A contribution to the mechanism of the reaction, Tetrahedron, 25(4), 704-717 (1969)

https://doi.org/10.1016/0040-4020(69)85002-7
21. Széll, T., Balaspiri, L.: Preparation of $2-14 \mathrm{CH}_{3}-3$-methyl-5,7dihydroxy-chromone: An approach to the nature of its formation. Acta Univ. Szegediensis, Acta Phys. Chem., 13(3-4), 117-119 (1967). https://doi.org/10.1016/0009-8981(66)90275-0

22. Széll, T. : Synthesis of 2,3-disubstituted chromones: cyclisation of the enolesters of $\boldsymbol{o}$-acyloxyphenyl alkyl ketones. J. Chem. Soc. C, 1967, 2041-2044 https://doi.org/10.1039/J39670002041

23. Furka, Á., Széll, T.: Fries reaction. Part I. Isomerisation of thymyl acetate. J. Chem. Soc., 1960, 2312-2321

24. Gerecs, Á., Széll, T., Windholz, M.: Beiträge zur Rolle der Salzsäure bei der Fries Reaktion. 1. Acta Chim. Hung., 3, 459-461 (1953)

25. Egyed, J., Furka, Á., Széll, T.: Fries Rearrangement of 3-Nitrophenyl-3-Nitrobenzoate. Acta Univ. Szegediensis, Acta Phys. Chem., 11, 51-54 (1965) https://doi.org/10.1111/j.1651-2227.1965.tb15605.x

26. Széll, T., Egyed, J.: Fries Rearrangement of 3-Nitrophenyl Butyrate J. Org. Chem., 27(6), 2225-2226 (1962) https://doi.org/10.1021/jo01053a514

27. Széll, T., Hajas, É., Sipos, Gy.: Preparation of Nitrohydroxyketones by Friedel-Crafts reactions. Acta Univ. Szegediensis, Acta Phys. Chem., 11, $47-50$ (1965)

28. Széll, T., Eastham, A. M. : Co-catalysis in Friedel-Crafts reactions. Part IX. Polymerisation of propene by boron fluoride-methanol. J. Chem. Soc. B, 1966, 30-33 https://doi.org/10.1039/J29660000030

29. Honeyman, A., Széll, T.: International baccalaureate chemistry J. Chem. Ed., 54(9), 562 (1977) https://doi.org/10.1021/ed054p562

30. Szell, T., Dennis, D., Jouas, J. P., Wong, M.: An approximate determination of Avogadro's constant. J. Chem. Education, 57(10), 735 (1980). https://doi.org/10.1021/ed057p735

31. Széll T.: A közép- és felsőfokú kémiaoktatás az USA-ban Magyar Kémikusok Lapja, 49, 365-370 (1994) https://doi.org/10.1111/j.1365-2044.1994.tb14217.x 


\section{Tamás Széll}

The international community of Hungarian chemists mourn for Tamás Széll, professor emeritus, DSc, one of the founders and one-time Head of the Department of Applied Chemistry at the University of Szeged, honorary habilitated professor of said university, former director of the International School Science Department of the UN in New York City, a member of New York Academies of Sciences, the American Chemical Society and the Royal Institute of Chemistry, who died last week.

Tamás Széll was born in Herény (close to Szombathely in West Hungary) in 1926. He completed his secondary school studies at the Premonstrant school in Szombathely, and the Jesuit 'Pius' school in Pécs. After his school leaving examinations (with 'excellent' result), following his father's and grandfather's example, he volunteered for the Hussars, and was in active service in Germany, where he became a prisoner of war first of the Americans, then of the Belgians. He managed to escape and returned to Hungary in 1944. He graduated (1950) with distinction from the Budapest Technical University as a chemical engineer, where he also earned his summa cum laude doctorate in engineering in 1961. While studying for his degree, he had been poor as a church mouse. Invited by Professor Árpád Gerecs to the University of Szeged, they co-founded the Department of Applied Chemistry, Tamás Széll was later appointed its Head. He obtained a teacher's diploma and university doctorate in chemistry in 1958. At the Hungarian Academy of Sciences, he became a candidate (old-style PhD) in 1960, and a Doctor of Science in 1974 - he specifically returned to Hungary from the US to obtain this academic degree.

Tamás Széll taught Chemical technology (both lecture and practice), Mechanical drawing and Industrial safety at the University of Szeged. He introduced the teaching of Industrial safety at university.

He got married in 1952. He met his future wife, Klára Molnár, when she was a student of chemical engineering at the University of Szeged. They had two daughters, four grandchildren and two great-grandchildren.

Tamás Széll won a five-year-long scholarship by open competition of the International School Science Department of the UN in New York City in 1970 where he worked as a teacher, later the director of the science department until his retirement in 1989. Meanwhile, he also worked as the director of the UNIS Dreyfus research programme between 1974 and 1982. He owed the UN scholarship to his excellent English which he had improved during his study trips in Canada (Ottawa, 1963-1965) and India (Calcutta, Ahmedabad, Jaipur, Madras, 1967). After the UN scholarship, the School asked him to stay on. His family had joined him in the USA, and one of his daughters married an American, so he applied for a prolongation of his permit to stay abroad from the Hungarian authorities, but his application was refused. Then he decided to stay anyway in the US, even without permission. This was a serious crime called 'defection' at that time. This decision meant that he would not be allowed to go home for a long time as he was sentenced to two years imprisonment in his absence. Several years later, he was allowed brief visits in Hungary with a so-called consular passport. Leaving his home caused a serious inner crisis, and he felt home- sick all his life. He was a proud Hungarian and remained faithful to his native country unto death. His patriotism, his affection for his homeland became apparent in his every act, writing or word. He kept his Hungarian citizenship as well.

As soon as it was possible, he came home practically every year, he flew across the Atlantic more than fifty times. He held courses and lectures, chaired secondary school leaving examinations, flew home to defend his academic doctoral thesis, habilitated at the University of Szeged, visited relations, friends and the cemeteries where members of his family rested.

The professional activity of Professor Széll focused on teaching, but he was also an excellent researcher. His research field was the organic synthetic chemistry, in particular the KostaneckiRobinson and the Aldol condensation, thus the synthesis of calcons and cromones, the $\mathrm{AlCl}_{3}$ catalyzed processes, the FriedlCrafts reaction and the Fries rearrangement. He invented a new cromone synthesis. While studying the Kostanecki-Robinson reaction mechanism which plays an important role in flavanoid research, he observed a process occurring with so-called neighbouring group participation.

Several dozen papers on teaching methodology published in national and international journals prove Tamás Széll's commitment to pedagogy and didactics.

Professor Széll was a highly accomplished, erudite, all-round Renaissance type man. He travelled extensively, visited five continents, spoke several languages, knew and loved classical literature and music, read much and played a few musical instruments. Genealogy was his passion. He painted skilfully, translated poems, and wrote fiction as well as nonfiction about Islam, environment, for example, the hole in the ozone layer and the climate warming, carbon dioxide in Earth's atmosphere, or the origin of the noon bell.

Tamás Széll was a friendly, cheerful, likeable man. Since he was an excellent teacher, his students adored him. His colleagues liked him without exception, and he had many friends. He was fond of animals, particularly dogs and horses. He enjoyed hiking and cycling, and he did sports even at an advanced age, regularly swam and worked in the garden. After his retirement, he bought a house in Essex (Vermont) so as to be close to his daughter, Ágnes and his grandchildren. In the unspoilt natural environment, he produced vegetables, planted trees and gladly watched the visiting forest animals - deer, fox, coyote - even when they did damage in his 'plantations.'

His last will and testament stipulates that his ashes will be brought back to Hungary and buried in the cemetery of Herény. His exile for half a century will be over. The homesickness which tortured him for many years will end forever, the wound inflicted upon him by his forced leave of home has healed. Only the memory of a patriotic and loyal fellow countryman, the all-round, gifted and learned man, the devoted teacher, the excellent chemist, the congenial, jolly, affable, honourable personality remains with us, his family, relatives, friends, students and chemist colleagues. 